\title{
Experimental Assessment of the Relationships Between Electrical Resistivity, Crustal Melting and Strain Localization beneath the Himalayan-Tibetan Belt
}

Leïla Hashim $^{1,2,3}$, Fabrice Gaillard ${ }^{1,2,3}$, Rémi Champallier ${ }^{1,2,3}$, Nicole Le Breton ${ }^{1,2,3}$, Laurent Arbaret $^{1,2,3}$, Bruno Scaillet $^{1,2,3}$

\section{Affiliations:}

${ }^{1}$ Université d'Orléans, ISTO, UMR 7327, 45071 Orléans, France.

${ }^{2}$ CNRS/INSU, ISTO, UMR 7327, 45071 Orléans, France.

${ }^{3}$ BRGM, ISTO, UMR 7327, BP 36009, 45060 Orléans, France.

*Correspondence to:

leila.hashim@univ-orleans.fr

Institut des Sciences de la Terre d'Orléans

UMR 7327 - CNRS/Université d'Orléans

1A, Rue de la Férollerie

45071 OrléansCedex 2

France

T: +33(0)23825 5394

F: $+33(0) 238636488$ 
Abstract: Seismic and magnetotelluric field campaigns carried out across the Himalaya and the Tibetan Plateau show mid-crustal low resistivity and low velocity zones. Interpretation of these anomalous observations, either saline fluids or partial melts, is still largely debated partly because experimental data simulating crustal melting under relevant pressure, temperature and water content conditions have not been provided. We report laboratory measurements constraining the resistivity as a function of temperature and the viscosity at $800^{\circ} \mathrm{C}$ of natural metapelite during partial melting. Dehydration-melting of muscovite is simulated using a Paterson press at $300 \mathrm{MPa}$ in the temperature range 600$850^{\circ} \mathrm{C}$. Electrical resistivity has been measured from the solid state $\left(<650^{\circ} \mathrm{C}\right)$ to $25 \mathrm{vol} . \%$ of partial melt $\left(>800^{\circ} \mathrm{C}\right)$ and viscosity has been determined at $800^{\circ} \mathrm{C}$. Our results together with recent experimental constrains on seismic properties of partially molten rocks strongly suggest that the electrical and seismic anomalies measured underneath the Himalayan-Tibetan collisional orogen are best explained by partially molten rocks or local accumulation of pure melt bodies. This is also remarkably corroborated by the temperature-depth conditions of crustal partial melting and melt ponding expected from petrological surveys in the Himalayan range. However, our data suggest much higher melt fraction than previously thought and this implies regions in the middle crust having viscosities several orders of magnitude lower than previously assumed. High degree partial melting in the middle crust of the Himalayan-Tibetan orogenic system suggests revision of conceptual models on the development of mountain belts or that geophysical models addressing electrical resistivity at depth must be reevaluated.

Keywords: Electrical resistivity; viscosity; partial melting

\section{Introduction}

The construction of mountain belts resulting from continental collisions involves crustal thickening, regional deformation and high-grade metamorphism. As observed in many 
ancient orogenic terrains, elevated temperatures locally induce melting and strain weakening, which may profoundly affect the rheology of the continental crust, its deformation regime and hence the development of these orogens (Jamieson et al., 2011; Sawyer et al., 2011).

The Himalaya-Tibetan system is an active collisional belt allowing us to probe the three-dimensional thermo-mechanical distribution of an archetypal continent-continent orogen. The Himalaya-Tibetan orogenic system was initiated 70-50 My ago by the IndoAsian collision resulting in crustal thickening and uplifting of the Tibetan Plateau (Royden et al., 2008; Yin and Harrison, 2000). This vast plateau is separated from the Himalayan mountains by the Indus-Tsangpo suture. Two major faults are located south of this suture: the Main Central Thrust (MCT), which is a low angle high strain crustal shear zone, and the South Tibetan Detachment system (STDs), a low angle normal fault (Fig. 1). The MCT and the STDs bound the Greater Himalayan Sequence (GHS), composed of medium to highgrade metamorphic rocks, migmatites (i.e. once partially molten rocks) and km-thick leucogranites pods (Law et al., 2004; Searle et al., 2006). These High Himalayan Leucogranites (HHL, Fig. 1), late Oligocene to Miocene in age (25-13 Ma), have been shown to be products of partial melting $\left(750-800^{\circ} \mathrm{C}\right.$ ) of underlying metapelites (Law et al., 2004; Patiño Douce and Harris, 1998; Scaillet et al., 1995; Searle et al., 2006). However, north of the Indus-Tsangpo suture young granitoids $(<15 \mathrm{Ma})$ are typically biotitegranodiorites with ${ }^{3} \mathrm{He}$ anomalies indicating a mantle contribution (Harrison, 2006; Hoke et al., 2000; Yokoyama et al., 1999).

Several magnetotelluric (MT) and seismic field campaigns (INDEPTH, Hi-CLIMB and HIMPROBE projects) have identified low resistivity layers with well-constrained tops at a depth of $10-15 \mathrm{~km}$ in southern Tibet (3 $\Omega . \mathrm{m}$ ) and 20-25 km in northwestern Himalaya (10 S.m), coincident with low seismic velocity zones (Arora et al., 2007; Brown et al., 1996; Caldwell et al., 2009; Hetényi et al., 2011; Li et al., 2003; Makovsky and Klemperer, 1999; 
Nábělek et al., 2009; Nelson et al., 1996; Unsworth et al., 2005; Wei et al., 2001; Zhao et al., 1993). Such electrical anomalies have been interpreted as evidence of high fluid concentrations and two main hypotheses are still largely debated today: either aqueous fluids (Hetényi et al., 2011; Li et al., 2003; Makovsky and Klemperer, 1999) or melts (Arora et al., 2007; Brown et al., 1996; Caldwell et al., 2009; Gaillard et al., 2004; Li et al., 2003; Nábělek et al., 2009; Nelson et al., 1996; Unsworth et al., 2005; Wei et al., 2001). However, both hypotheses remain poorly demonstrated (Harrison, 2006; Hetényi et al., 2011), each having considerable impact on the thermal structure of the thickened crust in the Himalayas. The melt hypothesis suggests low melt percentages, between 2 and 14 vol.\%, from electrical constraints (Arora et al., 2007; Unsworth et al., 2005), which would be in agreement with seismic observations (Caldwell et al., 2009) (less than $10 \mathrm{vol} . \%$ for $\mathrm{V}_{\mathrm{S}}=2.9-3.3 \mathrm{~km} . \mathrm{s}^{-1}$ ). Recent experimental shear wave velocity measurements (Caricchi et al., 2008), however, indicate that such velocities better match 20-25 vol.\% partial melting. Experimental studies on the electrical resistivity of partially molten rocks have been carried out on dry granulite samples at atmospheric pressures (Roberts and Tyburczy, 1999; Schilling and Partzsch, 2001). Under these conditions, partial melting starts at temperatures higher than $1000^{\circ} \mathrm{C}$, which is well above expected crustal temperatures in continent-collisional settings. Melts produced by crustal melting are hydrous (Scaillet et al., 1995), which implies lower melting temperatures and lower electrical resistivity of rocks and melts (Gaillard et al., 2004). Notwithstanding, resistivity values on hydrous partially molten metapelites are still not well constrained from electrical modelling such as SIGMELTS (Pommier and Le Trong, 2011).

In this experimental study, we have performed electrical resistivity measurements as a function of temperature and determined the viscosity of metapelites undergoing partial melting at $800^{\circ} \mathrm{C}$. These experiments were conducted using a Paterson-type deformation apparatus on partially molten metapelites. By using these types of rocks in this study, we have 
simulated the appropriate geological processes happening at depth according to previous petrological studies in the Himalayan-Tibetan range (Law et al., 2004; Patiño Douce and Harris, 1998; Scaillet et al., 1995; Searle et al., 2006). We therefore show here that the geophysical anomalies underneath this orogenic system must pinpoint high degree crustal melting and local melt accumulation, forming low-viscous regions, which are several orders of magnitude weaker than previously assumed (Beaumont et al., 2001, 2004, 2006; Jamieson et al., 2004; Medvedev and Beaumont, 2006). These results suggest revision of conceptual models on the development of mountain belts.

\section{Materials and Methods}

\subsection{Starting Material}

The starting material is a natural metapelitic rock from the Sioule metamorphic series (two-micas paragneiss formation, Supplementary Fig. 1), which belongs to the central metamorphic domain of the European Hercynian Belt (Faure et al., 2002). The Hercynian chain resulted from the collision of Gondwana and Laurussia in the Late Devonian-Early Carboniferous. The Sioule metamorphic series show strong evidence of partial melting and leucogranite emplacements similar to the Himalayan systems (Faure et al., 2002).

The composition of the Sioule sample we used (Table 1) is essentially similar to the Himalayan metapelite samples used by Patiño Douce and Harris (1998). The starting material contains Na-plagioclase, muscovite, biotite, quartz and K-feldspar in order of abundances (Table 1). Its composition and texture indicate no involvement in partial melting events and did not suffer any associated chemical depletions (in alkalis and water). Small amount of graphite $(<0.5$ vol.\%) has been observed in thin sections. The bulk composition, i.e. major elements and water content, was obtained from electron microprobe (EMP) and Fourier transformed infrared (FTIR) analyses, respectively, on a glass that has been rapidly quenched after total melting of this rock at high-pressure high-temperature $\left(4 \mathrm{~kb}, 1170^{\circ} \mathrm{C}, 21\right.$ hours). 
This melting experiment was conducted in an internally heated pressure vessel at Institut des Sciences de la Terre d'Orléans (ISTO) (see Iacono-Marziano et al., 2012). The total water content of the glass analysed by FTIR is 1.75 wt. $\%$ and a large amount of dissolved $\mathrm{CO}_{2}$ has been observed (1000 ppm $\mathrm{CO}_{2}$ ). This $\mathrm{CO}_{2}$ most likely derives from graphite oxidation during high temperature melting.

Oxygen fugacity of all the experiments presented in this paper was buffered by the coexistence of graphite and $\mathrm{CO}_{2}$ in the sample (observed after the runs). This corresponds to redox conditions close to FMQ-2 and mimics natural conditions of crustal melting that also occurs at graphite saturation (Pichavant et al., 1996).

Published experiments (Patiño Douce and Harris, 1998) and our results show that the dehydration-melting of muscovite starts at $650^{\circ} \mathrm{C}$ at $300 \mathrm{MPa}$. Previous experimental work established the following reaction (Patiño Douce and Harris, 1998):

$$
22 \mathrm{Ms}+7 \mathrm{Pl}+8 \mathrm{Qz} \rightarrow 25 \mathrm{Melt}+5 \mathrm{Kfs}+5 \mathrm{Sil}+2 \mathrm{Bt}
$$

Reaction 1

with Ms standing for muscovite, Pl for plagioclase, Qz for quartz, Kfs for K-feldspar, Sil for sillimanite and Bt for biotite.

Reaction 1 indicates that water, liberated upon muscovite breakdown, induces partial melting and incorporates into the melt, with about 1.14 volume of melt produced for 1 volume of muscovite. As our sample contains 23 vol. \% Ms, completion of reaction 1 induces 26.2 vol. \% melt in the rock.

\subsection{Electrical resistivity measurements}

The conventional Paterson assembly was modified in order to measure the resistance of the samples (Fig. 2). The sample-electrode geometry is similar to the configuration used by Caricchi et al. (2011). For resistivity measurements, an inner Ni electrode was inserted in the centre of the sample (perpendicularly to the layering configuration) and an outer Pt foil was 
placed around the samples. The resistance of the samples was measured along their radii, between the inner Ni electrode and the outer Pt foil. The compositional difference between the two electrodes had no effect on the collected resistance values. The electrical resistivity, $\rho$ ( $\Omega . \mathrm{m})$, was obtained from the resistance, $\mathrm{R}(\Omega)$, using (Caricchi et al., 2011; Gaillard, 2004; Pommier et al., 2008):

$\rho=\left(2 * \pi * L^{*} \mathrm{R}\right) /\left(\ln \left(\mathrm{d}_{\mathrm{ext}} / \mathrm{d}_{\mathrm{int}}\right)\right.$

with $L$ the length of the sample $(m), d_{\text {ext }}$ the outer diameter of the sample $(m)$ and $d_{\text {int }}$ the diameter of the inner electrode (m).

Electrical resistivity measurements were collected solely under static conditions (i.e. without applied deformation) in the temperature range of 500 to $850^{\circ} \mathrm{C}$ at $300 \mathrm{MPa}$ and at frequencies between $1 \mathrm{~Hz}$ and $1 \mathrm{MHz}$. Error on the calculated resistivity values is estimated to less than $7 \%$ except for run PP216 where the maximum error is of about $28 \%$ for temperatures $<690^{\circ} \mathrm{C}$ (Table 2). These estimations are based on the geometrical constraints of the samples (width, length, inner diameter) and on repeated electrical measurements at the same experimental conditions.

The electrical response of the samples is plotted at each frequency in the Nyquist plane (-Z', Z'') since the complex impedance (Z) can be written as the sum of real (Z') and imaginary ( $\left.Z^{\prime \prime}\right)$ components (where $Z=Z '+j Z '$ and $j^{2}=-1$ ). In this plane, the electrical response is an arc centred on the real axis where the first part of this arc (high frequencies) represents the electrical response of the sample whereas the second low-frequency arc is related to the sample/electrode interactions (Huebner and Dillenburg, 1995; Supplementary Fig. 2). The impedance arcs from this study can be fitted by a parallel circuit of a resistance and a capacitance (Huebner and Dillenburg, 1995; Roberts and Tyburczy, 1991).

\subsection{Rheological measurements}


Deformation experiments were performed at a pressure of $300 \mathrm{MPa}$ and at a temperature of $800^{\circ} \mathrm{C}$. During dynamic experiments, strain rates, $\gamma$ dot, range from $1 \cdot 10^{-5}$ to $2.5 \cdot 10^{-4} \mathrm{~s}^{-1}$ and bulk finite strain, $\gamma$, reaches a maximum value of 0.91 (Table 2). Strain rates were controlled by applying a continuous torque during the experiments. Stepping strain rate experiments were also conducted in order to calculate the stress exponent, $n$, enabling us to calculate the stress $\tau(\mathrm{MPa})$ from the applied torque $(\mathrm{Nm})$. Stepping strain rate consists of increasing strain rate in a stepwise manner once steady state stress conditions were achieved for a given strain rate (Paterson and Olgaard, 2000). Apparent viscosities, $\eta_{\mathrm{a}}(\mathrm{Pa} . \mathrm{s})$, of our samples were calculated for a given strain rate by using the following equation (Paterson and Olgaard, 2000):

$\eta_{\mathrm{a}}=\tau / \gamma \operatorname{dot}$

with $\tau$ the shear stress $(\mathrm{Pa})$ and $\gamma$ dot, the strain rate $\left(\mathrm{s}^{-1}\right)$.

\subsection{Analytical techniques and imaging}

After the static and dynamic experiments, the samples were cut along longitudinal axial sections (Fig. 7 in Paterson and Olgaard (2000)) and then mounted in epoxy. A scanning electron microscope (SEM) was used for microscopic observations at back-scattered electron mode at ISTO (see Supplementary Figs. 3, 4 and 5). Melt distribution and volumetric percentages were determined by manually selecting the melt phase (consisting of glass and crystals formed from reaction 1) on SEM images of the radial faces of the samples (Supplementary Figs. 3 and 4). Binary images were created with solely the melt appearing in black. Volumetric percentages were then calculated using a ratio of pixels of melt over the total pixels of the studied binary image (Table 2).

Chemical compositions of bulk rock and mineral phases as well as the melt produced by dehydration-melting of muscovite crystals were obtained by EMP analyses. The water 
content (in the glass) of the bulk rock was analysed by FTIR following Iacono-Marziano et al. (2012).

\section{Experimental Strategy}

To better constrain electrical resistivity values during our Paterson experiments, we have conducted partial melting experiments in internally heated pressure vessels at ISTO (PM experiments, Supplementary Materials). These partial melting experiments have enabled us to constrain the onset of partial melting in the temperature range $650-700^{\circ} \mathrm{C}$ (Supplementary Table 1; Supplementary Fig. 5), which is in agreement with published phase equilibria experiments on similar mineralogical assemblages (Patiño Douce and Harris, 1998). In the latter study, the associated melt production, via reaction 1 , is completed at $\mathrm{T}=820^{\circ} \mathrm{C}$.

Partial melting of metapelites has also been shown to be an extremely slow process. Previous studies reveal that run durations of one week are not sufficient to achieve equilibrium melt percentages at temperatures lower than $800^{\circ} \mathrm{C}$ (Rubie and Brearly, 1990). Indeed, Rubie and Brearly (1990) have shown that the melting kinetics of a reaction involving muscovite, quartz and $\mathrm{H}_{2} \mathrm{O}$ is controlled by diffusion of $\mathrm{Si}, \mathrm{Al}$ and $\mathrm{K}$ through the melt for temperatures $<760^{\circ} \mathrm{C}$. The width of the reaction zone between muscovite and quartz is a square root function of time and is modelled by a parabolic law, which indicates that at least two weeks are required to fully dissolve small muscovite grains. Textural and crystal-melt chemical equilibrations at $\mathrm{T}<800^{\circ} \mathrm{C}$ thus operate at rates that are not compatible with the duration of experiments in Paterson apparatus.

Our time-series resistivity measurements performed at temperatures ranging from 650 to $825^{\circ} \mathrm{C}$ (PP187, PP202, PP205; Table 2) didn't show any clear electrical stabilization. We have interpreted this behaviour as a record of slow chemical and textural evolution of the samples during partial melting (Supplementary Fig. 6). To counteract this effect and obtain chemical and textural equilibrium, the temperature was increased to $850^{\circ} \mathrm{C}$ (PP213, $\mathrm{PP} 214$, 
PP216; Table 2), enhancing reaction kinetics and leading to nearly electrical steady state within $~ 300$ min (Supplementary Fig. 7). Such high temperature ensured the rapid and total melting of muscovite. For the reason explained below (see section 5.1), the results used in this study for interpreting MT anomalies beneath the Tibetan-Himalayan range are essentially based on those from experiments with peak temperatures of $850^{\circ} \mathrm{C}(\mathrm{PP} 213, \mathrm{PP} 214$ and PP216; Table 2). During these experiments, we linearly increased the temperature to $500^{\circ} \mathrm{C}$ and then increased by $50^{\circ} \mathrm{C}$ steps up to $850^{\circ} \mathrm{C}$, enabling us to perform resistivity measurements at different constant temperatures. After annealing the samples at $850^{\circ} \mathrm{C}$, the temperature was decreased to $800^{\circ} \mathrm{C}$, which corresponds to established temperatures of melt extraction as suggested by geochemical, experimental and field observations in the Himalayas (Patiño Douce and Harris, 1998; Searle et al., 1997). Long static resistivity measurements or viscosity experiments were thus conducted separately at $800^{\circ} \mathrm{C}$ after the annealing stage. Electrical resistivities were then measured during cooling cycles (Fig. 4 and Supplementary Fig. 8).

\section{Results}

\subsection{Chemical composition of the produced melt}

EMP analyses show that the melt produced during our partial melting experiments is granitic in composition and analogous to the High Himalayan Leucogranites (Scaillet et al., 1995; Table 1). It has typical high $\mathrm{SiO}_{2}$ contents (>70 wt. \%) and high water contents (>6 wt. $\%$ based on the difference to $100 \%$, see Table 1). This composition was analysed in run PP214 after equilibration at a peak temperature of $850^{\circ} \mathrm{C}$. Liquid compositions analysed in other experiments were relatively similar, but the low melt fraction did not allow us to obtain precise chemical analyses.

\subsection{Electrical resistivity}


Replicated experiments showed a good reproducibility during heating stages (Fig. 3) in spite of the variable sample geometries (length, layering configuration). As temperature increases from 550 to $825^{\circ} \mathrm{C}$, the electrical resistivity of the metapelites decreases dramatically from $\sim 2000$ to $20 \Omega . \mathrm{m}$. The onset of partial melting, optically identified from the PM-experiments presented in section 3, is also indicated by a slope shift (i.e. a change in electrical properties) between 650 and $700^{\circ} \mathrm{C}$ on Fig. 3.

Figure 4 presents the resistivity measurements from experiment PP216 during both heating and cooling cycles (after a peak $\mathrm{T}$ at $850^{\circ} \mathrm{C}$ ). As illustrated on this figure, the resistivity/temperature path is shifted toward less resistive values during cooling cycles. The difference between heating and cooling cycles is significant but remains reasonably low except for temperatures $<650^{\circ} \mathrm{C}$, where this discrepancy reaches at least one order of magnitude. Furthermore, between 850 and $550^{\circ} \mathrm{C}$ during the cooling cycle, melt percentage remains constant at 23 vol. $\%$.

\subsection{Viscosity}

Image analyses (Supplementary Figs. 3 and 4) revealed no migration and accumulation of melt throughout the deformed samples. The samples deformed homogeneously since no strain localization was observed.

We have determined the stress exponent, $n$, of our material, corresponding to the slope of a logarithmic plot of shear strain rate versus maximum measured torque (Supplementary Fig. 9). Despite our small strain rate/torque data set, the calculated $n(n=5.44)$ is in good agreement with a previous study on the rheology of synthetic metapelitic samples undergoing partial melting ( $n=5.15$; Misra et al., 2009).

The mechanical behaviour of our metapelitic samples is summarized in a shear stress versus shear strain plot (Fig. 5). These rheological measurements show a rapid linear increase, corresponding to the elastic response of the stressed sample, followed by either steady state 
flow or moderate weakening during plastic deformation (Fig. 5). Peak stress values vary with peak temperature: as temperature increases, melt percentage increases, thus weakening the metapelitic sample. The significant peak stress value difference between runs PP187-PP202 and runs PP213-PP216 is therefore directly related to their corresponding peak temperatures $\left(825^{\circ} \mathrm{C}\right.$ and $850^{\circ} \mathrm{C}$, respectively). Figure 5 and Table 2 also indicate good reproducibility for equivalent strain rates and peak temperatures (experiments PP213 and PP216 for $\mathrm{T}_{\text {peak }}=$ $850^{\circ} \mathrm{C}$ and $\left.\gamma \operatorname{dot}=2.5 \cdot 10^{-4} \mathrm{~s}^{-1}\right)$.

Experiments PP187 and PP202 $\left(\mathrm{T}_{\text {peak }}=825^{\circ} \mathrm{C}\right.$ and $\gamma$ dot $\left.=1 \cdot 10^{-5}-1 \cdot 10^{-4} \mathrm{~s}^{-1}\right)$ present calculated apparent viscosities, $\eta_{\mathrm{A}}$, ranging from $10^{12.32}$ to $10^{11.38}$ Pa.s, whereas experiments PP213 and PP216 $\left(\mathrm{T}_{\text {peak }}=850^{\circ} \mathrm{C}\right.$ and $\gamma$ dot $\left.=1 \cdot 10^{-5}-2.5 \cdot 10^{-4} \mathrm{~s}^{-1}\right)$ present $\eta_{\mathrm{A}}$ ranging from $10^{11.69}$ to $10^{10.56}$ Pa.s (Table 2).

\section{Discussion}

\subsection{Equilibrated melt percentage/temperature/resistivity paths}

At $300 \mathrm{MPa}$ during heating cycles, melt percentage increases continuously from 0 vol. $\%$ at $550^{\circ} \mathrm{C}$ to 23 vol. $\%$ at $850^{\circ} \mathrm{C}$ (Fig. 4; Supplementary Table 1), indicating slow melting kinetics because melt fraction is expected to abruptly increase once muscovite breakdown temperature is exceeded. Likewise, during cooling cycles, the low resistivity/temperature paths were interpreted as slow kinetics of crystallization, as melt percentage remains at 23 vol. \% even at the lowest temperature $\left(500^{\circ} \mathrm{C}\right.$, Fig. 4$)$. We have thus calculated the variations of equilibrium melt percentage as a function of $\mathrm{P}$ and $\mathrm{T}$ by creating a $\mathrm{P}-\mathrm{T}$ pseudosection (Supplementary Fig. 10), using the collection of thermodynamic modelling programs Perple_X 6.6.6. (Connolly, 1990, 2005; Connolly and Kerrick, 1987; Connolly and Petrini, 2002). The bulk composition of the system used for calculations is that of our metapelitic sample together with 1.75 wt. \% water. Melt percentage is modelled by using the program PyWerami (http://petrol.natur.cuni.cz/ ondro/pywerami:home, Fig. 6). At $300 \mathrm{MPa}$, the 
calculated equilibrium melt percentage increases from 0 to more than 15 vol. $\%$ within a few degrees as a consequence of the dehydration-melting of muscovite in fluid absent conditions. This strong and abrupt increase in melt mode is not observed during heating cycles of the present study due to a sluggish melting rate. The P-T pseudosection (Supplementary Fig. 10) indicates that above the solidus temperature $\left(\mathrm{T}_{\mathrm{S}}=650^{\circ} \mathrm{C}\right.$ at $\left.300 \mathrm{MPa}\right)$, the partially molten samples in our experiments are in disequilibrium, thus overestimating the electrical resistivity values. Measurements collected during the cooling cycles therefore represent a very close assessment of the resistivity of equilibrated partially molten metapelites at temperatures just above the temperature of muscovite dehydration-melting $\left(650^{\circ} \mathrm{C}<\mathrm{T}<700^{\circ} \mathrm{C}\right.$ at $\left.300 \mathrm{MPa}\right)$.

Therefore, in our experiments $(\mathrm{P}=300 \mathrm{MPa})$, we considered that the equilibrated resistivity/temperature path should follow the solid-state path during the heating cycle until the solidus temperature is reached $\left(650^{\circ} \mathrm{C}<\mathrm{T}_{\mathrm{S}}<700^{\circ} \mathrm{C}\right)$. Above $\mathrm{T}_{\mathrm{S}}$, resistivity should be shifted within a few degrees Celsius to values corresponding to 23 vol. \% partial melting during the cooling cycle (bold dashed line at $300 \mathrm{MPa}$ for $\mathrm{T}>650^{\circ} \mathrm{C}$ in Fig. 4). The equilibrated resistivity/temperature path varies with pressure, as $\mathrm{T}_{\mathrm{S}}$ increases with increasing pressure (from $675^{\circ} \mathrm{C}$ at $500 \mathrm{MPa}$ to $745^{\circ} \mathrm{C}$ at $900 \mathrm{MPa}$; Fig. 6). This $\mathrm{T}_{\mathrm{S}} /$ pressure-dependence therefore shifts the abrupt decrease in electrical resistivity to higher temperatures. As an example, the equilibrated resistivity/temperature path at $700 \mathrm{MPa}$ is shown to abruptly decrease by $1-\log$ unit at $\mathrm{T}_{\mathrm{S}}=720^{\circ} \mathrm{C}$ (Fig. 4).

\subsection{Electrical resistivity of solid and liquid end-members}

Since HHL pods are presently outcropping in the GHS (Fig. 1), we have calculated the electrical resistivity of crystal-free leucogranite magma bodies as extrapolated from our partial melting experiments. Electrical resistivity is commonly estimated by using mixing models where the bulk resistivity of the sample depends on the electrical resistivities of the 
present phases (in this study, melt and solid), as well as their relative volumes and geometrical distributions in the sample.

We were able to extrapolate the electrical resistivity of the produced melt by using our experimental and previously published data and mixing models (Table 3; Gaillard and Marziano, 2005; Yoshino et al., 2012). For brevity, only a few mixing models were used in this section: Archie's law, which is an empirically derived relation (Archie, 1942); the modified Archie's law, which is derived from the Archie's law using geometrical constraints (Glover et al., 2000); Hashin-Shtrikman upper bound (Hashin and Shtrikman, 1962); the cubes model (Waff, 1974) and the tubes model (Grant and West, 1965; Schmeling, 1986).

The electrical resistivity of the solid was adjusted from the low temperature data $\left(<650^{\circ} \mathrm{C}\right)$ collected during our experiments as follows:

$\ln \rho_{\mathrm{s}}=-\ln \rho_{0}+(-\mathrm{Ea} /(\mathrm{RT}))$

with

$\rho_{0}=2.90 \pm 0.20$ and $\mathrm{Ea} / \mathrm{R}=-8581.80 \pm 600.73$

where $\rho_{\mathrm{S}}$ is the resistivity of the solid rock in $\Omega . \mathrm{m} ; \rho_{0}$, the pre-exponential term in $\Omega . \mathrm{m}$; Ea, the activation energy in $\mathrm{J}$; $\mathrm{R}$, the gas constant; $\mathrm{T}$, the temperature in $\mathrm{K}$.

The graphite in our sample shows no noticeable effect on the electrical resistivity of our solid-state samples during heating stages (Fig.4). Indeed, measured conductivities are typical of solid-state crustal rocks (Ferri et al., 2013; Schilling and Partzsch, 2001), whereas interconnected graphite in our sample should enhance conductivities by several orders of magnitude (Shankland et al., 1993; Yoshino and Noritake, 2011). This experimental observation on natural metapelite is in agreement with previous experimental studies performed on graphite-rich xenoliths (Ferri et al., 2013) and C-rich synthetic quartz aggregates (Yoshino and Noritake, 2011). 
We used the bulk resistivity value collected at $800^{\circ} \mathrm{C}$ during the cooling cycle, once the samples presented an electrical steady state $\left(\rho_{B}=11.97 \Omega . m\right)$ to calculate the resistivity of the melt. Image analyses showed that this sample contained 23 vol. \% partial melting.

Calculations show that melt resistivities are essentially similar for Archie's law, the Hashin-Shtrikman upper bound and the cubes model (between 1.87 and 2.13 S.m, Table 3). Melt resistivity values calculated using the tube model and the modified Archie's law are however slightly lower and higher, respectively (0.97 and 2.71 $\Omega . \mathrm{m}$, respectively, Table 3). Electrical resistivity of hydrated granitic melts was also calculated following equations by Gaillard (2004):

$\rho=\left(\sigma_{0} * \exp \left(-\mathrm{E}_{\mathrm{a}} /(\mathrm{RT})\right)^{-1}\right.$

with

$\sigma_{0}=-78.9 * \ln \left(\mathrm{H}_{2} \mathrm{O}\right)+754$ and $\mathrm{E}_{\mathrm{a}}=-2925 * \ln \left(\mathrm{H}_{2} \mathrm{O}\right)+70132$

where $\mathrm{T}$ is the temperature in $\mathrm{K}$ and $\mathrm{H}_{2} \mathrm{O}$ the water content in wt. \% (natural logarithm). For granitic liquids containing 6 wt. $\%$ of dissolved $\mathrm{H}_{2} \mathrm{O}$ at $800^{\circ} \mathrm{C}$, equation (4) yields $2.35 \Omega . \mathrm{m}$, which is in remarkable agreement with the liquid resistivity independently estimated from partial melting experiments and mixing models.

\subsection{Cross-checking petrological, geophysical and laboratory constraints}

Laboratory work and thermobarometric studies (Patiño Douce and Harris, 1998) indicate that melting of the Himalayan metapelites occurred at a pressure equivalent to $18-24$ $\mathrm{km}$ depth and a temperature of $750-800^{\circ} \mathrm{C}$ (Fig. 7), which according to our experimental data correspond to a resistivity of $10 \Omega . m$ (Fig. 8). As shown in Fig. 7, such resistivity-depthtemperature conditions are fully compatible with the northwestern Himalayan electrical anomaly. Furthermore, the high melt percentage deduced from our study yields the 
appropriate shear wave velocities observed in this region (Caldwell et al., 2009; Caricchi et al., 2008).

Electrical resistivity was calculated during cooling and crystallization of leucogranites (Fig. 8; Scaillet et al., 1995). Due to the near-eutectic composition of such magmas, the resistivity moderately increases to $\sim 15 \Omega . \mathrm{m}$ as temperature decreases to $650^{\circ} \mathrm{C}$ (i.e. 30 vol.\% crystals), whereas in the temperature range $650-645^{\circ} \mathrm{C}$, where the bulk crystallization occurs, the resistivity increases by several orders of magnitude (Fig. 8). Experimental studies show that HHL were emplaced as near-liquidus magma with a depth of $\sim 12 \mathrm{~km}$ and a temperature of about $800^{\circ} \mathrm{C}$ (Fig. 7; Scaillet et al., 1995), which yields a resistivity of 3 S.m (Fig. 8). Such resistivity-depth-temperature conditions remarkably match the electrical anomaly detected beneath Southern Tibet (Fig. 7). Since shear waves do not propagate through liquid states, we suggest that spatial resolution of seismic analyses may not allow identification of fully molten bodies of limited vertical extents, such as sill-shaped or laccolith bodies.

Magnetotelluric profiles enable us to constrain the depth of the top of the electrical anomaly but can hardly constrain their thicknesses. We have based our experimental modelling exclusively on peak resistivity values from MT data of northwestern Himalaya and southern Tibet (10 and 3 S.m, respectively; Aurora et al., 2007; Unsworth et al., 2005). The resistivity values implied in this study yield anomaly thicknesses of about $23 \mathrm{~km}$ for northwestern Himalaya and $12 \mathrm{~km}$ for southern Tibet (Supplementary Fig. 11). There is however a tradeoff between the thickness of a low resistivity layer and the value of resistivity of that layer. We decided to adopt the values given in Aurora et al. (2007) and Unsworth et al. (2005) therefore knowingly ignoring this tradeoff. We suggest that a more realistic MTmodelling should be carried out by using our experimental electrical results, complemented by seismic data, but such considerations go beyond the scope of the present work.

\subsection{Viscosity implications}


Presence of partial melting and fully molten bodies has serious impact on the rheological behaviour of the middle crust. Indeed, our results show that crustal rocks with 2025 vol. \% partial melting (corresponding to the electrical anomaly of northwestern Himalaya) imply a viscosity, $\eta$, of $10^{11}$ Pa.s (Table 2). Our data seems in good agreement with the experimental study of Misra et al. (2009), where the apparent viscosity of their synthetic sample yielded a value of $10^{11.62} \mathrm{~Pa}$.s at a strain rate of $3 \cdot 10^{-4} \mathrm{~s}^{-1}$, at a temperature of $750^{\circ} \mathrm{C}$ and for comparable melt percentages.

Pure melts, corresponding to the electrical anomaly beneath southern Tibet, have been shown to present lower viscosities, i.e. $10^{4}$ Pa.s (Scaillet et al., 1996; Whittington et al., 2004). These two values (i.e. $10^{11} \mathrm{~Pa}$.s and $10^{4} \mathrm{~Pa} . \mathrm{s}$ ) are several orders of magnitude lower than previous estimations used in thermo-mechanical models of channel flow and crustal extrusion ( $\eta=10^{18}-10^{19}$ Pa.s) (Beaumont et al., 2001, 2004, 2006; Jamieson et al., 2004; Medvedev and Beaumont, 2006). Such low-viscosity regions provide a natural mechanism for localizing strain into the weakest parts of the deforming layers, as shown by previous field observations and demonstrated by experimental deformation studies (Brown, 2007; Kohlstedt and Holtzman, 2009; Marchildon and Brown, 2003; Rosenberg and Handy, 2005; Vanderhaeghe, 2009). Crustal melting in the Himalayan middle crust must therefore be an essential process in forming low-viscosity regions and thus crustal-scale thrusts and/or high strain shear zones, such as the STDs and the MCT (Fig. 1).

\subsection{The aqueous fluid hypothesis in conflict with geochemical and geophysical}

\section{observations}

We have found that the aqueous fluids hypothesis cannot completely satisfy combined constraints from metamorphic fluid salinity, electrical resistivities and seismic velocities. Firstly, the question of the geochemical origin of brines is raised since the presence of Cl-rich sources in the Himalayan-Tibetan crust remains unproved. Secondly, fluid inclusions within 
rocks from the GHS show high salinity content (25 wt. \% NaCl; Spencer et al., 2011), which implies a resistivity value of $\sim 75 \cdot 10^{-4} \Omega . \mathrm{m}$ (Nesbitt, 1993). By using electrical mixing models (as in section 5.2), we have found that the electrical anomalies beneath the Himalayan-Tibetan orogenic system (10 $\Omega . m-3 \Omega . m$ in Northwestern Himalaya and Southern Tibet, respectively) are best explained by $\sim 0.8$ vol. $\%$ of connected brines for the aqueous fluid hypothesis (Supplementary Table 2). Such a low brine percentage cannot explain the corresponding low seismic velocity zone, which requires at least 10 vol.\% fluids (Makovsky and Klemperer, 1999).

Furthermore, by using the electrical mixing models we have determined that 10 vol.\% interconnected aqueous fluids would yield a resistivity value of $\sim 0.11 \Omega$.m. This calculated value is two orders of magnitude lower than the values assessed by MT-field campaigns (10

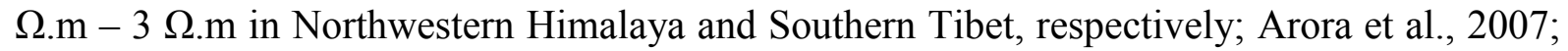
Li et al., 2003; Unsworth et al., 2005; Wei et al., 2001). The aqueous fluids hypothesis therefore yields a substantial discrepancy between seismic and electrical constraints.

\section{Conclusion}

New electrical resistivity measurements on partially molten metapelites have shown that the electrical anomalies detected by geophysical surveys beneath southern Tibet $(3 \Omega . \mathrm{m})$ and northwestern Himalaya (10 $\Omega . \mathrm{m})$ remarkably match fully molten leucogranite bodies and 25 vol. \% partially molten metapelites, respectively. Our study therefore corroborates that the processes (i.e. partial melting of metapelites and subsequent melt segregation) that generated the 25-13 Ma HHL must still be operating at depth beneath the Himalayan-Tibetan belt. Whether these processes are local or regional phenomena remains to be ascertained (Harrison, 2006; Hetényi et al., 2011).

The high melt percentages and corresponding viscosity values acquired during our experiments represent a benchmark for thermo-mechanical models, which must be calibrated 
against this inescapable constraint. The implementation of the electrical-seismic-petrologicalthermal-rheology relationships made possible with our study constitutes a requirement for understanding which factors in such thermo-mechanical models are most likely to influence orogenic processes and therefore in improving our knowledge of the development and sustainment of large-scale orogens.

We finally suggest that forward modelling based on our laboratory electrical measurements and petrological-thermobarometric models of the Himalayan-Tibetan range should be confronted to field data from MT studies. Such an integrated methodology might lead to a revision of the minimum resistivity, translating into revised melt fractions, viscosity and strain localisations in the mid-crustal range. 


\section{Acknowledgements}

This paper is part of L.H.'s PhD supported by the French Ministère de l'Enseignement Supérieur et de la Recherche. This research is funded by the European Research Council, ERC, (grant number 279097) and by the ANR (grant number ANR-10-BLAN-62101). The authors would like to thank Mark Harrison for careful and efficient editorial handling as well as four anonymous reviewers for constructive comments that significantly improved this paper. We would also like to acknowledge Ida Di Carlo for analytical support, Mickael Laumonier for constructive discussions, Esteban Le Moing and Philippe Teulat for technical assistance.

\section{References}

Archie, G.E., 1942. The electrical resistivity $\log$ as an aid in determining some reservoir characteristics, Trans. Am. Inst. Min. Metall. Pet. Eng. 146, 54-62.

Arora, B.R., Unsworth, M.J., Rawat, G., 2007. Deep resistivity structure of the northwest Indian Himalaya and its tectonic implications. Geophys. Res. Lett. 34, L04307, doi: 10.1029/2006GL029165.

Beaumont, C., Jamieson, R.A., Nguyen, M.H., Lee, B., 2001. Himalayan tectonics explained by extrusion of a low-viscosity crustal channel coupled to focused surface denudation. Nature 414, 738-742.

Beaumont, C., Jamieson, R.A., Nguyen, M.H., Medvedev, M., 2004. Crustal channel flows 1: Numerical models with application to the tectonics of the Himalayan-Tibetan orogeny. J. Geophys. Res. 109, B06406. doi: 10.1029/2003JB002809.

Beaumont, C., Nguyen, M.H., Jamieson, R.A., Ellis, S., 2006. Crustal flow modes in large hot orogens. In: Law, R.D., Searle, M.P., Godin, L. (Eds.), Channel Flow, Ductile Extrusion and Exhumation in Continental Collision Zones, Geol. Soc. London Spec. Publ. London, pp. $91-145$. 
Brown, M., 2007. Crustal melting and melt extraction, ascent and emplacement in orogens: mechanisms and consequences. J. Geol. Soc. London 164, 709-730.

Brown, L.D., Zhao, W., Nelson, K.D., Hauck, M., Alsdorf, D., Ross, A., Cogan, M., Clark, M., Liu, X., Che, J., 1996. Bright spots, structure and magmatism in southern Tibet from INDEPTH seismic reflection profiling. Science 274, 1688-1690.

Caldwell, W.B., Klemperer, S.L., Rai, S.S., Lawrence, J.F., 2009. Partial melt in the uppermiddle crust of northwest Himalaya revealed by Rayleigh wave dispersion. Tectonophysics 477, 58-65.

Caricchi, L., Burlini, L., Ulmer, P., 2008. Propagation of P and S-waves in magmas with different crystal contents: Insights into the crystallinity of magmatic reservoirs. J. Volcanol. Geotherm. Res. 178, 740-750.

Caricchi, L., Gaillard, F., Mecklenburgh, J., Le Trong, E., 2011. Determination of electrical conductivity during deformation of melt-bearing olivine aggregates: Implications for electrical anisotropy in the oceanic low velocity zone. Earth Planet. Sci. Lett. 302, 81-94.

Connolly, J.A.D., 1990. Multivariable phase-diagrams: an algorithm based on generalized thermodynamics. Am. J. Sci. 290, 666-718.

Connolly, J.A.D., 2005. Computation of phase equilibria by linear programming: A tool for geodynamic modeling and its application to subduction zone decarbonation. Earth Planet. Sci. Lett. 236, 524-54.

Connolly, J.A.D., Kerrick, D.M., 1987. An algorithm based on generalized thermodynamics. CALPHAD 11, 1-55.

Connolly, J.A.D., Petrini, K., 2002. An automated strategy for calculation of phase diagram sections and retrieval of rock properties as a function of physical conditions. J. Metamorph. Petrol. 20, 697-708. 
Faure, M., Monié, P., Pin, C., Maluski, H., Leloix, C., 2002. Late Visean thermal event in the northern part of the French Massif Central: new ${ }^{40} \mathrm{Ar} /{ }^{39} \mathrm{Ar}$ and $\mathrm{Rb}-\mathrm{Sr}$ isotopic constraints on the Hercyniansyn-orogenic extension, Int. J. Earth Sci. 91. doi: $10.1007 / \mathrm{s} 005310100202$.

Ferri, F., Gibert, B., Violay, M., Cesare, B., 2013. Electrical conductivity in partially molten crust from measurements on metasedimentary enclaves. Tectonophysics 586, 84-94.

Gaillard, F., 2004. Laboratory measurements of electrical conductivity of hydrous and dry silicic melts under pressure. Earth Planet. Sci. Lett. 218, 215-228.

Gaillard, F., Marziano, G.I., 2005. Electrical conductivity of magma in the course of crystallization controlled by their residual liquid composition. J. Geophys. Res. 110, B06204.doi:10.1029/2004JB003282.

Gaillard, F., Scaillet, B., Pichavant, M., 2004. Evidence for present-day leucogranite pluton growth in Tibet. Geology 32, 801-804.

Glover, P.W.J., Hole, M.J., Pous, J., 2000. A modified Archie's law for two conducting phases. Earth Planet. Sci. Lett. 180, 369-383.

Grant, F.S., West, G.F., 1965. Introduction to electrical methods. In Schrock, R. R. (Ed.), Interpretation Theory in Applied Geophysics, McGraw-Hill. New York, pp. 385-401.

Harrison, T.M., 2006. Did the Himalayan Crystallines extrude partially molten from beneath the Tibetan Plateau. In: Law, R.D., Searle, M.P., Godin, L. (Eds.), Channel Flow, Ductile Extrusion and Exhumation in Continental Collision Zones, Geol. Soc. London Spec. Publ. London, pp. 237-254.

Hashin, Z., Shtrikman, S., 1962. A variational approach to the theory of effective magnetic permeability of multiphase materials. J. Appl. Phys. 33, 3125-3131. 
Hetényi, G., Vergne, J., Bollinger, L., Cattin, R., 2011. Discontinuous low-velocity zones in southern Tibet question the viability of the channel flow model. In: Gloaguen, R., Ratschbacher, L. (Eds.), Growth and Collapse of the Tibetan Plateau, Geol. Soc. London Spec. Publ. London, pp. 99-108.

Hoke, L., Lamb, S., Hilton, D.R., Poreda, R., 2000. Southern limit of mantle-derived geothermal helium emissions in Tibet: implications for lithospheric structure. Earth Planet. Sci. Lett. 180, 297-308.

Huebner, J.S., Dillenburg, R.G., 1995. Impedance spectra of hot, dry silicate minerals and rock: Qualitative interpretation of spectra. Am. Mineral. 80, 46-64.

Iacono-Marziano, G., Morizet, Y., Le Trong, E., Gaillard, F., 2012.New experimental data and semi-empirical parameterization of $\mathrm{CO}_{2}-\mathrm{H}_{2} \mathrm{O}$ solubility in mafic melts. Geochem. Cosmochim. Acta 97, 1-23.

Jamieson, R.A., Beaumont, C., Medvedev, S., Nguyen, M.H., 2004. Crustal channel flows: 2. Numerical models with implications for metamorphism in the Himalayan-Tibetan orogeny. Geophys. Res. Lett. 109, B06407.doi: 10.1029/2003JB002811.

Jamieson, R.A., Unsworth, M., Harris, N., Rosenberg, C.L., Schulmann, K., 2011. Crustal melting and the flow of mountains. Elements 7. doi: 10.2113/gselements.7.4.253.

Kohlstedt, D.L., Holtzman, B.K. 2009. Shearing melt out of the Earth: An experimentalist's perspective on the influence of deformation on melt extraction. Annu. Rev. Earth Planet. Sci. 37, 561-593.

Law, R.D, Searle, M.P., Simpson, R.L., 2004. Strain, deformation temperatures and vorticity of flow at the top of the Greater Himalayan Slab, Everest Massif, Tibet. J. Geol. Soc. London 161, 305-320. 
Li, S., Unsworth, M., Booker, J., Wei, W., Tan, H., Jones, A.G., 2003.Partial melt or aqueous fluid in the mid-crust of Southern Tibet? Constraints from INDEPTH magnetotelluric data.Geophys. J. Int. 153, 289-304.

Makovsky, Y., Klemperer, S.L., 1999. Measuring the seismic properties of Tibetan bright spots: Evidence for free aqueous fluids in the Tibetan middle crust. J. Geophys. Res. 104, 10,795-10,825. doi: 10.1029/1998JB900074.

Marchildon, N., Brown, M., 2003. Spatial distribution of melt-bearing structures in anatectic rocks from Southern Brittany, France: implications for melt transfer at grain- to orogenscale. Tectonophysics 364, 215-235.

Medvedev, S., Beaumont, C., 2006. Growth of continental plateaus by channel injection: models designed to address constraints and thermomechanical consistency. In: Law, R.D., Searle, M.P., Godin, L. (Eds.), Channel Flow, Ductile Extrusion and Exhumation in Continental Collision Zones, Geol. Soc. London Spec. Publ. London, pp. 147-164.

Misra, S., Burlini, L., Burg, J.P., 2009. Strain localization and melt segregation in deforming metapelites. Phys. Earth Planet. Int. 177, 173-179.

Nábělek, J., Hetényi, G., Vergne, J., Sapkota, S., Kafle, B., Jiang, M., Su, H., Chen, J., Huang, B.-S., the Hi-CLIMB Team, 2009.Underplating in the Himalaya-Tibet collision zone revealed by the Hi-CLIMB experiment. Science 325, 1371-1374.

Nelson, K.D., Zhao, W., Brown, L.D., Kuo, J., Che, J., Liu, X., Klemperer, S.L., Makovsky, Y., Meissner, R., Mechie, J., Kind, R., Wenzel, F., Ni, J., Nábělek, J., Leshou, C., Tan, H., Wei, W., Jones, A.G., Booker, J., Unsworth, M., Kidd, W.S.F., Hauck, M., Alsdorf, D., Ross, A., Cogan, M., Wu, C., Sandvol, E., Edwards, M., 1996. Partially molten middle crust beneath southern Tibet: Synthesis of Project INDEPTH results. Science 274, 16841688. 
Nesbitt, B.E., 1993. Electrical resistivities of crustal fluids. J. Geophys. Res. 98, 4301-4310.

Paterson, M.S., Olgaard, D.L., 2000. Rock deformation tests to large shear strains in torsion, J. Struct. Geol. 22, 1341-1358.

Patiño Douce, A., Harris, N., 1998. Experimental constraints on Himalayan anatexis. J. Petrol. 39, 689-710.

Pichavant, M., Hammouda, T., Scaillet, B., 1996. Control of redox state and Sr isotopic composition of granitic magmas: A critical evaluation of the role of source rocks. Trans. R. Soc. Edinburgh Earth Sci. 87, 321-329.

Pommier, A., Gaillard, F., Pichavant, M., Scaillet, B., 2008. Laboratory measurements of electrical conductivities of hydrous and dry Mount Vesuvius melts under pressure. J. Geophys. Res. 113, doi: 10.1029/2007JB005269.

Pommier, A., Le Trong, E., 2011. SIGMELTS: A web portal for electrical conductivity calculations in geosciences. Computers Geosciences 37, 1450-1459.

Roberts, J.J., Tyburczy, J.A., 1991. Frequency dependent electrical properties of polycrystalline olivine compacts. J. Geophys. Res. 96, 16,205-16,222.

Roberts, J.J., Tyburczy, J.A., 1999. Partial-melt electrical conductivity: Influence of melt composition. J. Geol. Res. 104, 7055-7065.

Rosenberg, C.L., Handy, M.R., 2005. Experimental deformation of partially melted granite revisited: implications for the continental crust. J. Metamorph. Geol. 23, 19-28.

Royden, L.H, Burchfield, B.C., van der Hilst, R.D., 2008. The geological evolution of the Tibetan Plateau. Science 321, 1054-1058. 
Rubie, D.C., Brearly, A.J., 1990. A model for rates of disequilibrium melting during metamorphism. In Ashworth, J.R., Brown, M. (Eds.), High-temperature metamorphism and crustal anatexis, Unwin Hyman. London, pp. 57-86.

Sawyer, E.D., Cesare, B., Brown, M., 2011. When the continental crust melts. Elements 7, 229-234.

Scaillet, B., Holtz, F., Pichavant, M., Schmidt, M., 1996. Viscosity of Himalayan leucogranites: Implications for mechanisms of granitic magma ascent. J. Geophys. Res. $101,27,691-27,699$.

Scaillet, B., Pichavant, M., Roux, J., 1995. Experimental crystallization of leucogranite magmas. J. Petrol. 36, 663-705.

Schilling, F.R., Partzsch, G.M., 2001. Quantifying partial melt fraction in the crust beneath the central Andes and the Tibetan Plateau. Phys. Chem. Earth 26, 239-246.

Schmeling, H., 1986. Numerical models on the influence of partial melt on elastic, anelastic and electrical properties of rocks. Part II: Electrical conductivity. Phys. Earth Planet. Inter. 43, 123-136.

Searle, M.P., Law, R.D., Jessup, M., 2006. Crustal structure, restoration and evolution of the Greater Himalaya in Nepal-South Tibet: implications for channel flow and ductile extrusion of the middle crust. In: Law, R.D., Searle, M.P., Godin, L. (Eds.), Channel Flow, Ductile Extrusion and Exhumation in Continental Collision Zones, Geol. Soc. London Spec. Publ. London, pp. 355-378.

Searle, M.P., Parrish, R.R., Hodges, K.V., Hurford, A., Ayres, M.W., Whitehouse, M.J., 1997. Shisha Pangmaleucogranite, south Tibetan Himalaya: Field relations, geochemistry, age, origin, and emplacement. J. Geol 105, 295-318. 
Shankland, T.J., Peyronneau, J., Poirier, J.P., 1993. Electrical conductivity of the Earth's lower mantle. Nature 366, 453-455.

Spencer, C.J., Harris, R.A., Sachan, H.K., Saxena, A., 2011. Depositional provenance of the Greater Himalayan Sequence, Garhwal Himalaya: Implications for tectonic setting. J. Asian Earth Sci. 41, 344-354.

Unsworth, M.J., Jones, A.G., Wei, W., Marquis, G., Gokarn, S.G., Spratt, J.E., Project INDEPTH Team, 2005. Crustal rheology of the Himalaya and southern Tibet inferred from magnetotelluric data. Nature 438, 78-81.

Vanderhaeghe, O., 2009. Migmatites, granites and orogeny: Flow modes of partially-molten rocks and magmas associated with melt/solid segregation in orogenic belts. Tectonophysics 477, 119-134.

Waff, H.S., 1974. Theoretical consideration of electrical conductivity in a partially molten mantle and implications for geothermometry. J. Geophys. Res 79, 4003-4010.

Wei, W., Unsworth, M., Jones, A.G., Booker, J., Tan, H., Nelson, K.D., Chen, L., Li, S., Solon, K., Bedrosian, P., 2001. Detection of widespread fluids in the tibetan crust by magnetotelluric studies. Science 292, 716-718.

Whittington, A.G., Richet, P., Behrens, H., Holtz, F., Scaillet, B., 2004. Experimental temperature- $\mathrm{X}\left(\mathrm{H}_{2} \mathrm{O}\right)$-viscosity relationship for leucogranites and comparison with synthetic silicic liquids. Trans. R. Soc. Edinburgh Earth Sci. 95, 59-71.

Yin, A., Harrison, T.M., 2000. Geologic evolution of the Himalayan-Tibetan orogen. Annu. Rev. Earth Planet. Sci. 28, 211-280.

Yokoyama, T., Nakai, S., Waikita, H., 1999. Helium and carbon isotopic compositions of hot spring gases in the Tibetan Plateau. J. Volcanol. Geotherm. Res. 88, 99-107. 
Yoshino, T., McIsaac, E., Laumonier, M., Katsura, T., 2012.Electrical conductivity of partial molten carbonate peridotite. Phys. Earth Planet. Int. 194-195, 1-9.

Yoshino, T., Noritake, F., 2011. Unstable graphite films on grain boundaries in crustal rocks. Earth Planet. Sci. Lett. 306, 186-192.

Zhao, W., Nelson K.D., Project INDEPTH Team, 1993. Deep Seismic reflection evidence for continental underthrusting beneath southern Tibet. Nature 366, 557-559. 


\section{Figure captions}
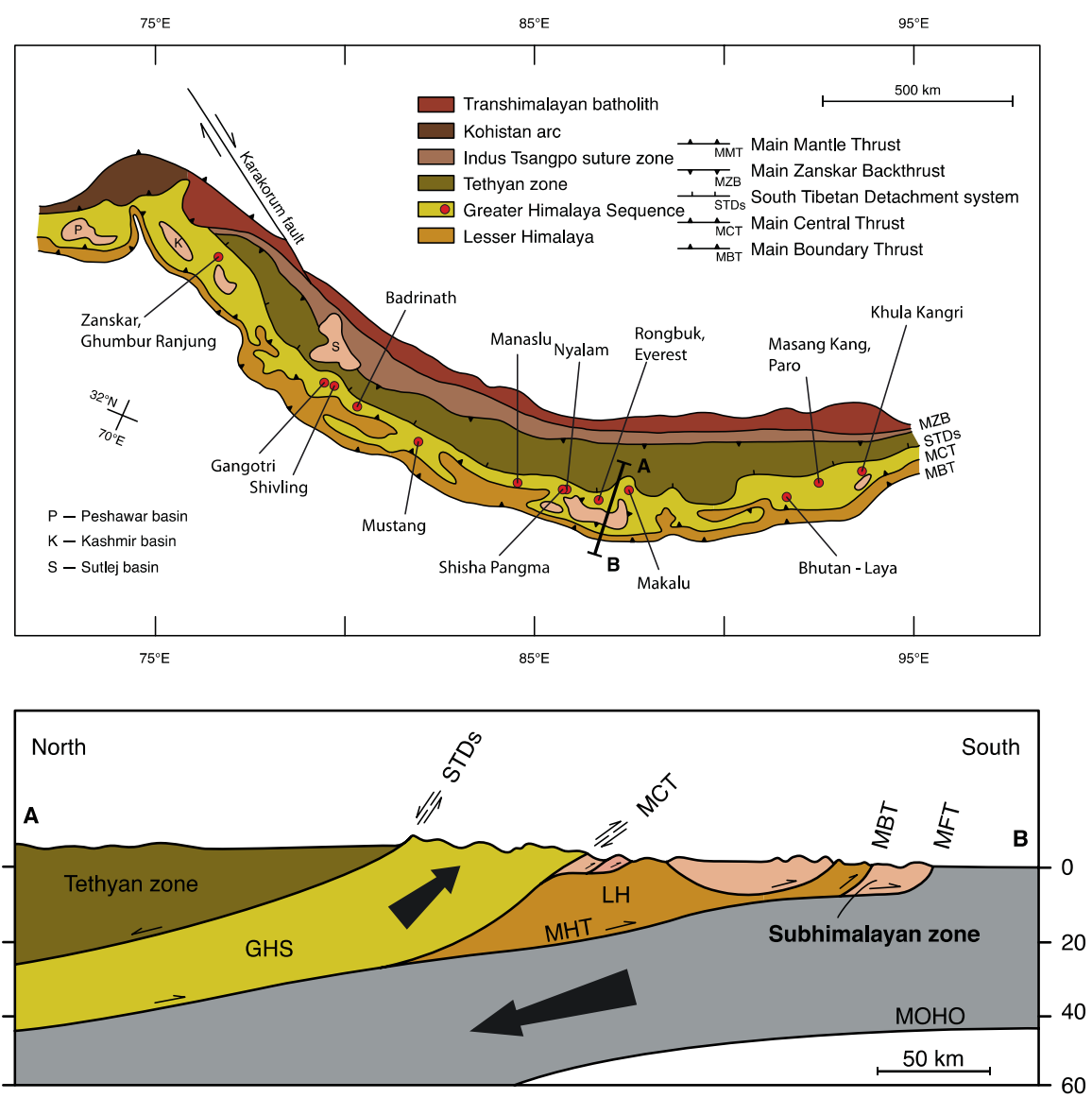

Figure 1. Simplified geological map and cross-section of the Himalaya showing the main High Himalayan Leucogranites (red dots) along the Greater Himalaya Sequence (adapted after Law et al. (2004) and Searle et al. (2006)). Abbreviations - GHS: Greater Himalaya Sequence; LH: Lesser Himalaya; STDs: South Tibetan Detachment system; MCT: Main Central Thrust; MBT: Main Boundary Thrust; MFT: Main Frontal Thrust; MHT: Main Himalayan Thrust; MOHO: Mohorovic discontinuity. 


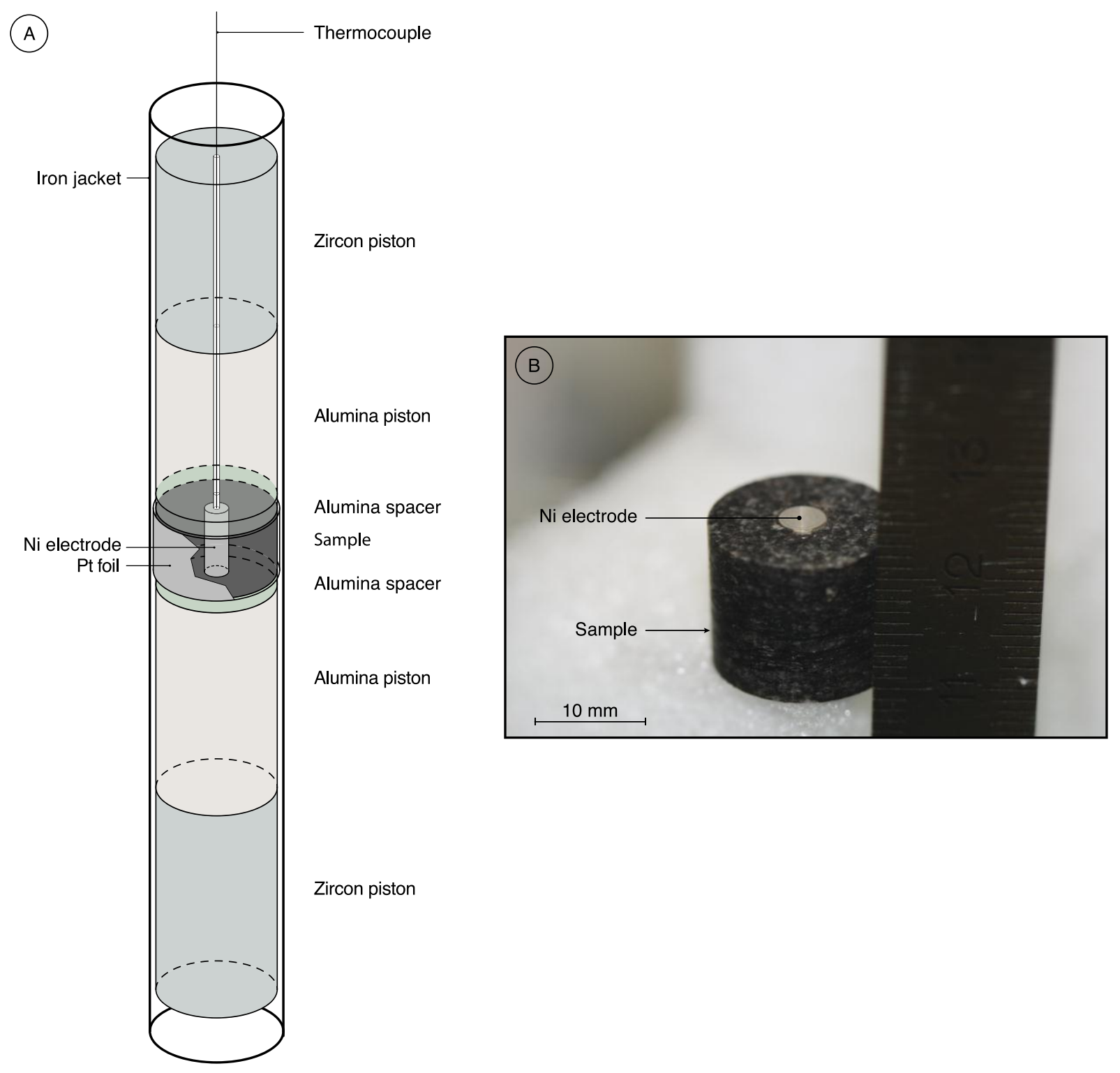

Figure 2. (A) Modified Paterson assembly used for electrical resistivity measurements. (B) Zoom of sample showing inner Ni electrode. 


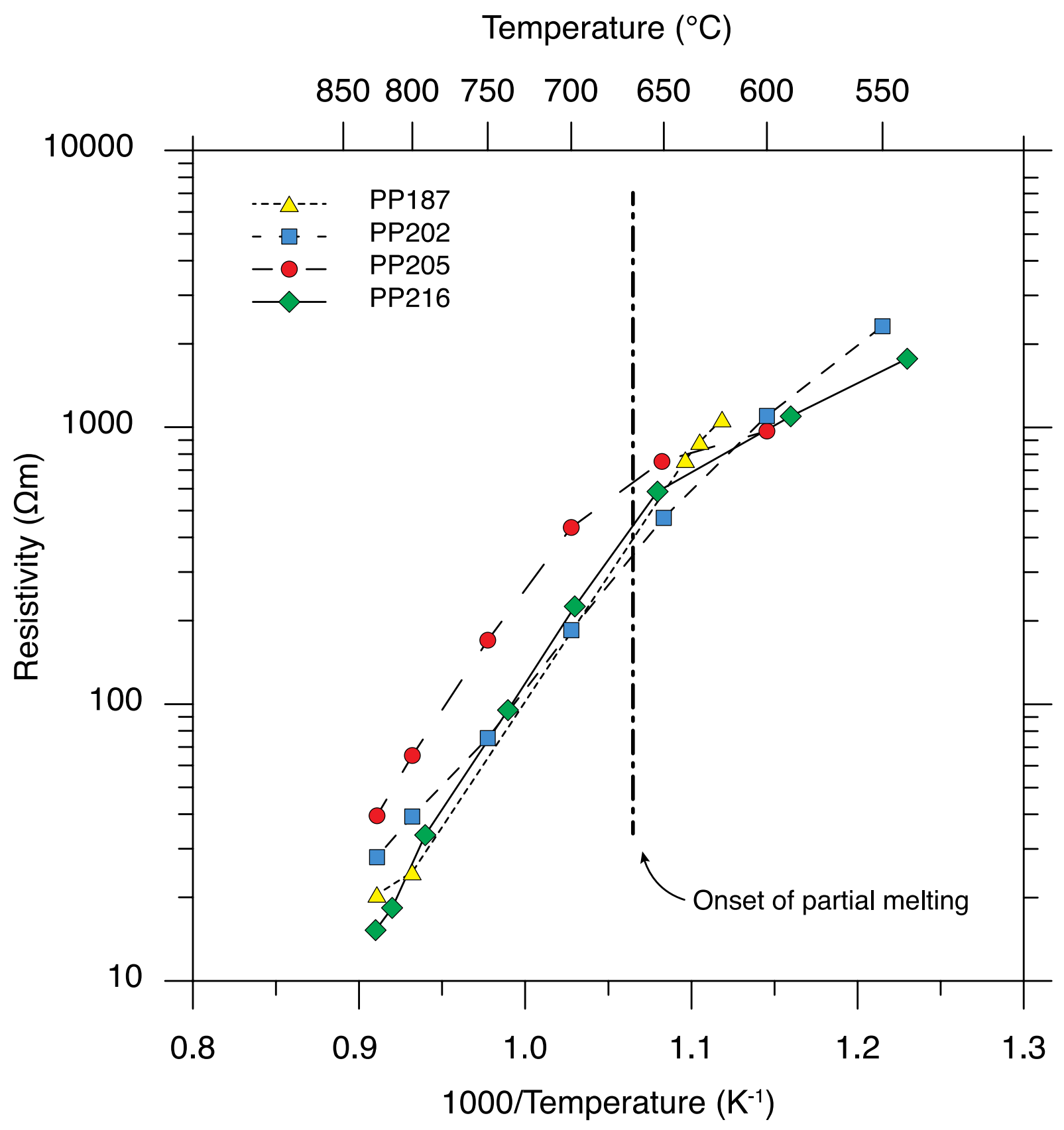

Figure 3. Measured electrical resistivities of runs PP187, PP202, PP205 and PP216 during heating cycles at $300 \mathrm{MPa}$. The plotted values represent electrical measurements after $\mathrm{t}$ $>60$ min. Error on the plotted electrical resistivity values is within the size of the data points. 


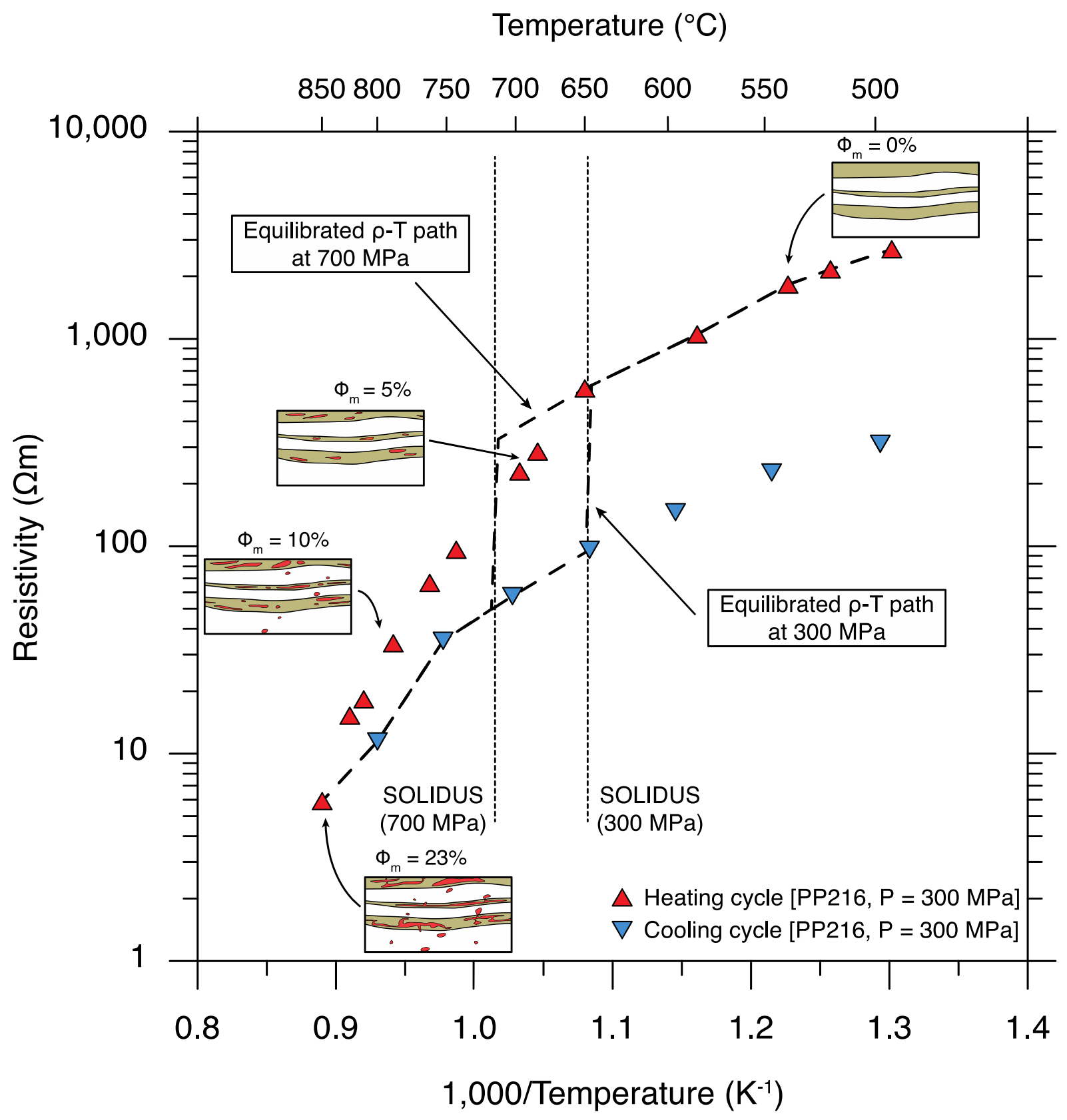

Figure 4. Electrical resistivity vs. temperature of experiment PP216 at $300 \mathrm{MPa}$ confining pressure. During the heating cycle (red triangles), melt percentage increases moderately from 0 to $23 \mathrm{vol}$. \%. During the cooling cycle (blue triangles), the sample remains partially molten (23 vol. \% melt), even at the lowest temperature $\left(500^{\circ} \mathrm{C}\right)$. This hysteresis cycle shows that the sample is in electrical disequilibrium. The equilibrated resistivity/temperature path (bold dashed lines) should follow the solid-state sample until the solidus temperature (e.g. solidi at 300 and $700 \mathrm{MPa}$ ), where the resistivity is shifted within a 
few degrees Celsius to lower values corresponding to 23 vol. \% partial melting. See text for more details. Error on the plotted electrical resistivity values is within the size of the data points. Abbreviation $-\Phi_{\mathrm{m}}$ : melt percentage; P: pressure. 


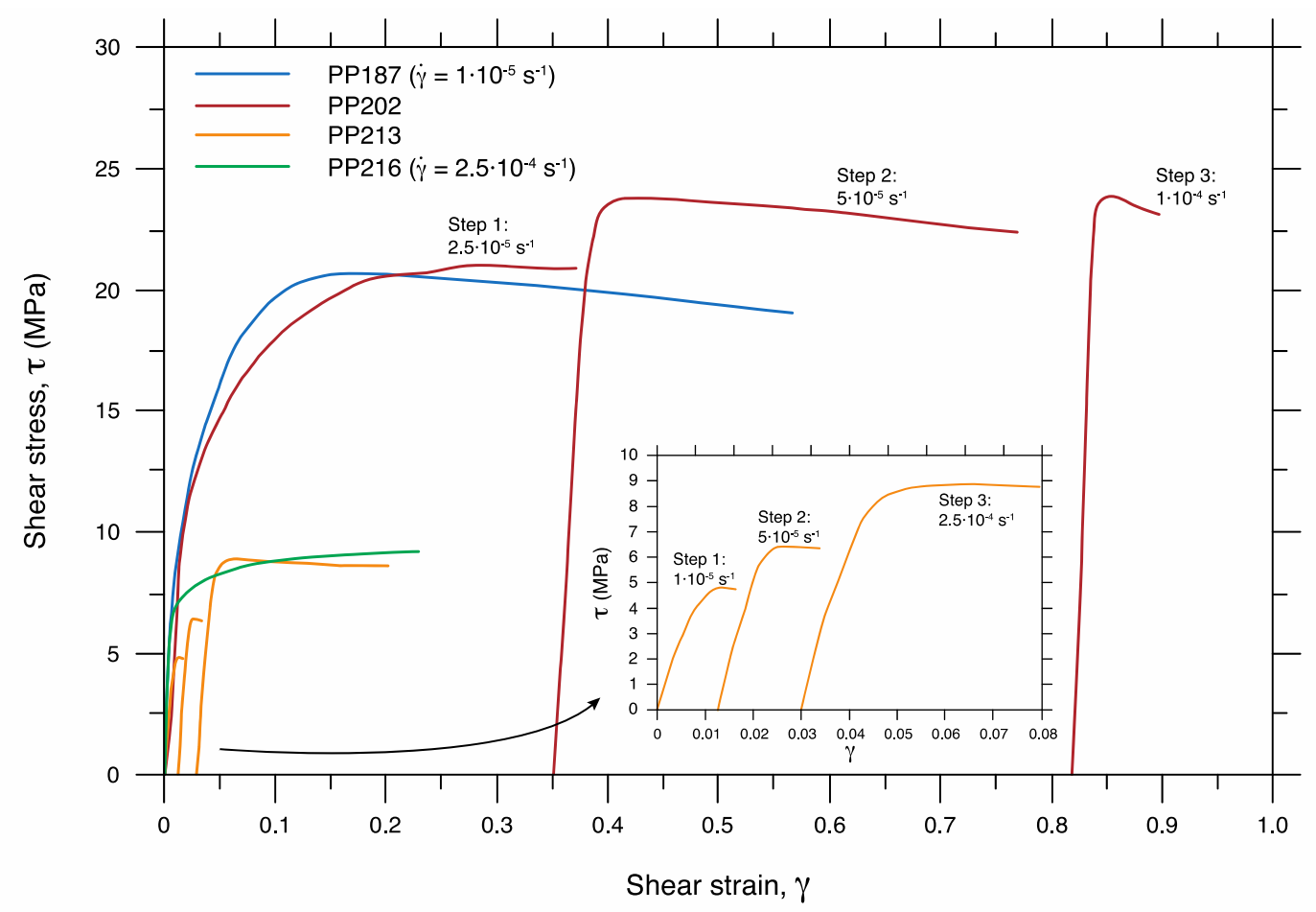

Figure 5. Mechanical behaviour of the metapelitic samples during runs PP187, PP202, PP213 and PP216. Experiments PP187 and PP216 were deformed at constant strain rate. Stepping strain rate experiments were undertaken during runs PP202 and PP213. 


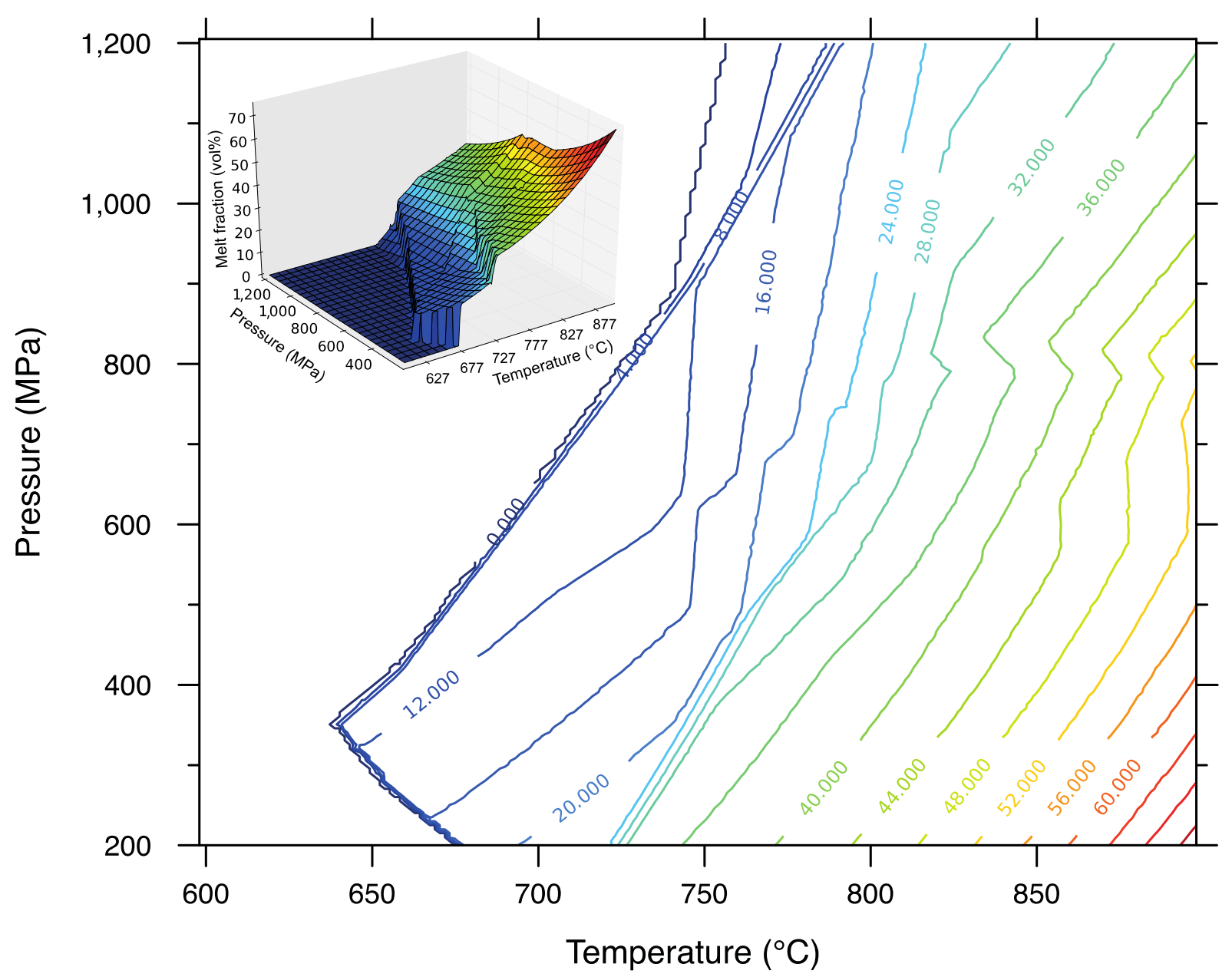

Figure 6. Melt percentages (vol. \%) calculated with Perple_X 6.6.6. for the chemical composition of the Sioule sample used as starting material in the present study. The water content of the system was fixed at $1.75 \mathrm{wt} \%$. The results are plotted in P-T diagrams (2D contours and 3D surface) with the program PyWerami. 


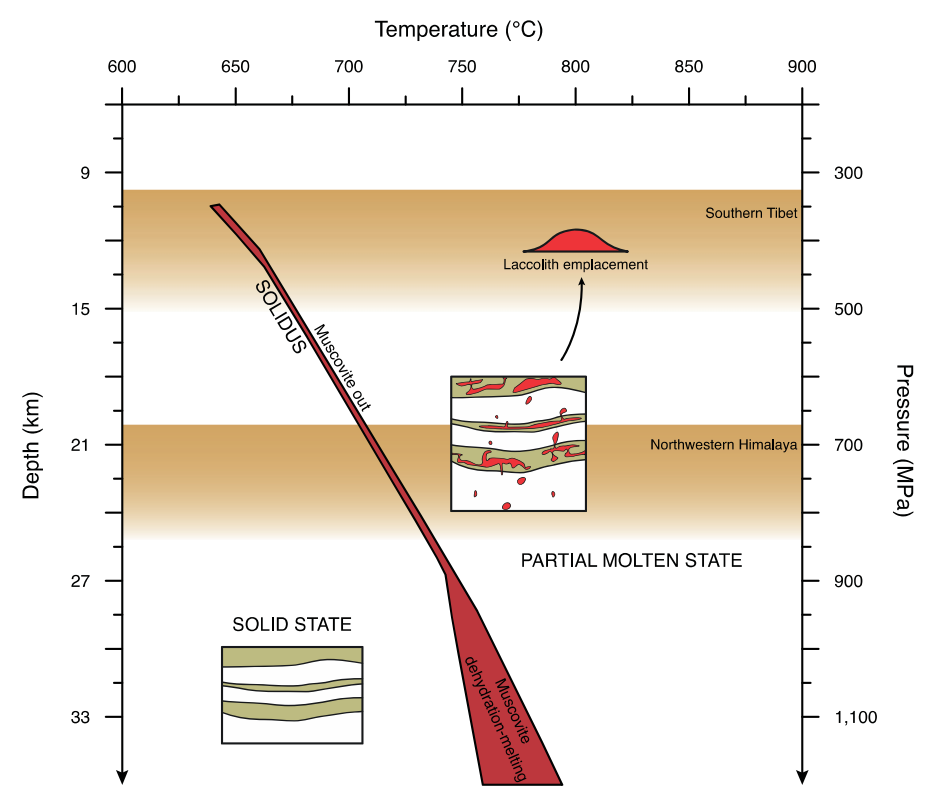

Figure 7. Pressure/depth versus temperature plot for partial melting of Himalayan metapelites. The red zone represents the dehydration-melting of muscovite in fluid absent conditions and isolates solid-state rocks (on the left-hand side of the red zone) from partially molten rocks (on the right-hand side of the red zone). In the Himalayan geological context, metapelites produce granitic melts in the temperature range $750-800^{\circ} \mathrm{C}$ and pressures between 600-800 MPa (Patiño Douce and Harris, 1998). High Himalayan Leucogranites emplace as near-liquidus magma at $800^{\circ} \mathrm{C}$ and $400 \mathrm{MPa}$ (Scaillet et al., 1995). Resistivity-depthtemperature conditions for Himalayan partial melting and leucogranite emplacement remarkably match the MT anomalies beneath this orogen. 


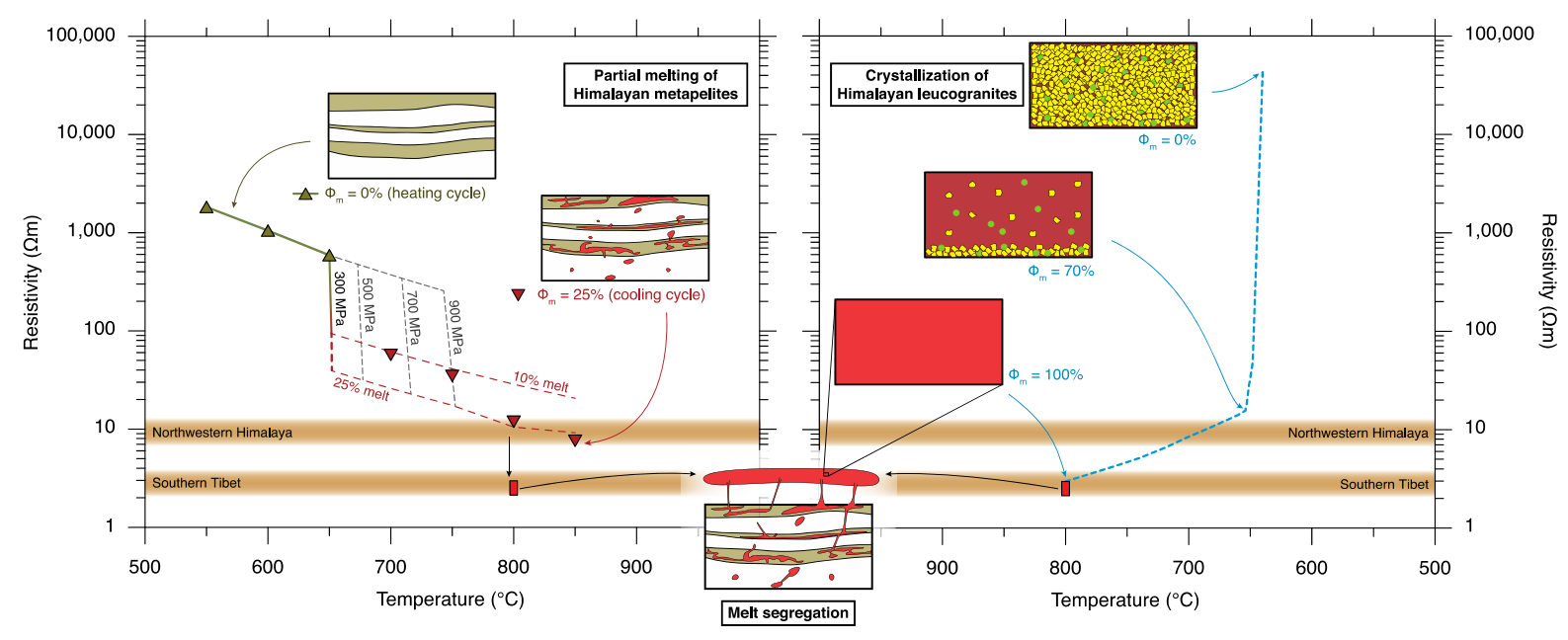

Figure 8. Electrical resistivity versus temperature for partial melting of Himalayan metapelites and crystallization of Himalayan leucogranites. Our experimental data is represented by the triangles in the left panel. At $650^{\circ} \mathrm{C}$ and $300 \mathrm{MPa}$, melt percentage increases from 0 to 10 vol. $\%$ within $5^{\circ} \mathrm{C}$, sharply decreasing the electrical resistivity. With increasing pressure, melting temperature increases, therefore shifting the sharp decrease in resistivity to higher temperatures. Resistivity mixing models are shown in red dashed lines, considering fully connected melt (10 and 25 vol.\% melt) in a solid matrix $\left(\mathrm{HS}^{+}\right)$. Extrapolation of fully molten bodies at $800^{\circ} \mathrm{C}$ from our partial melting experiments and mixing models is represented by red rectangles in both panels (lower and upper boundaries calculated using $\mathrm{HS}^{+}$and equation 5 by Gaillard (2004), respectively). The blue dotted line in the right panel corresponds to cooling and crystallization of leucogranitic bodies (experimental data from Scaillet et al. (1995) using $\mathrm{HS}^{+}$). MT anomalies can be explained by either 25 vol. $\%$ partial melting of the middle crust at $800^{\circ} \mathrm{C}$ or leucogranites containing 20 vol. \% crystals at $680^{\circ} \mathrm{C}$ for northwestern Himalaya and by emplacement of leucogranitic bodies at $800^{\circ} \mathrm{C}$ for southern Tibet. Abbreviation $-\Phi_{\mathrm{m}}$ : melt percentage. 
Table 1

Starting Sample

Produced melt

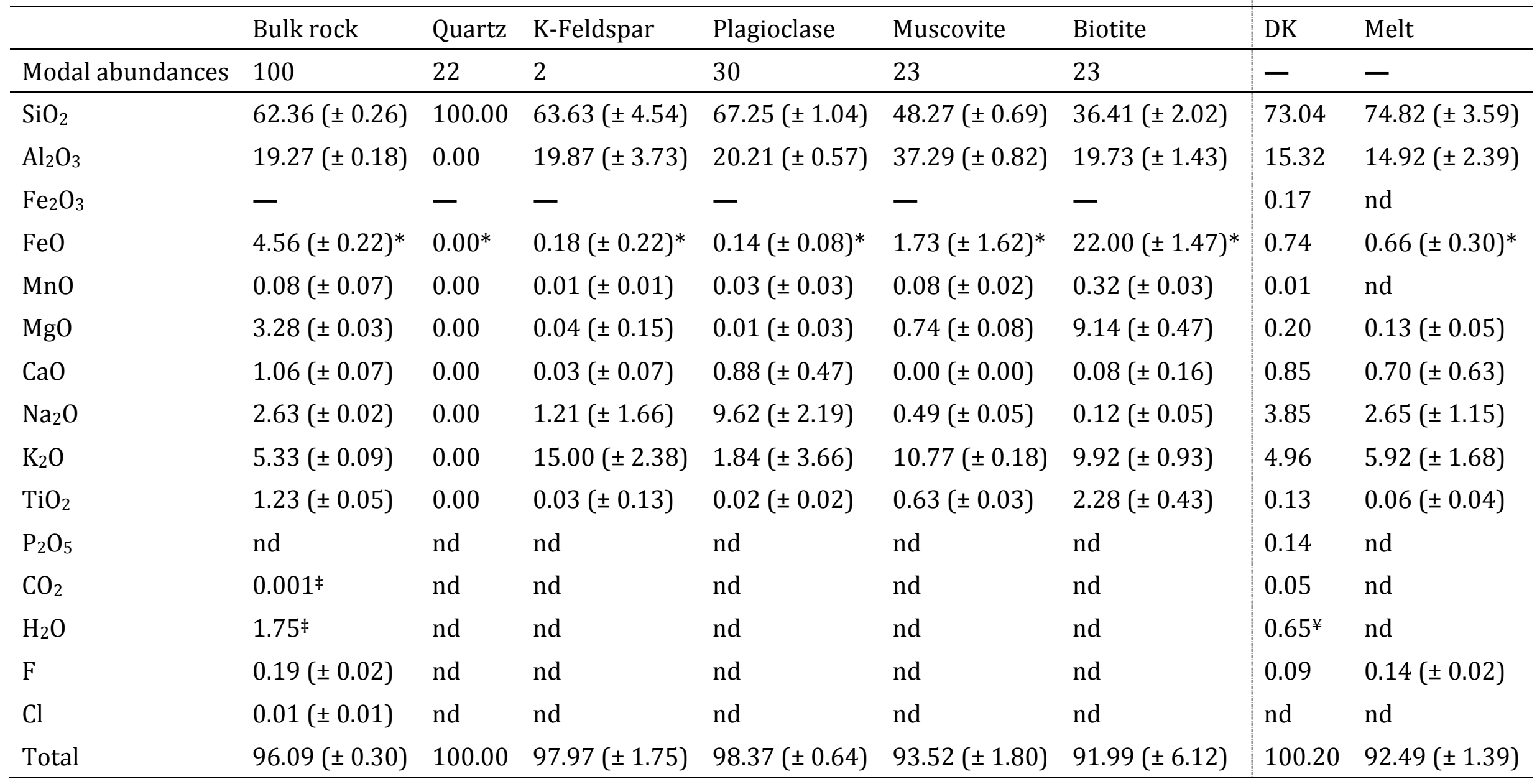




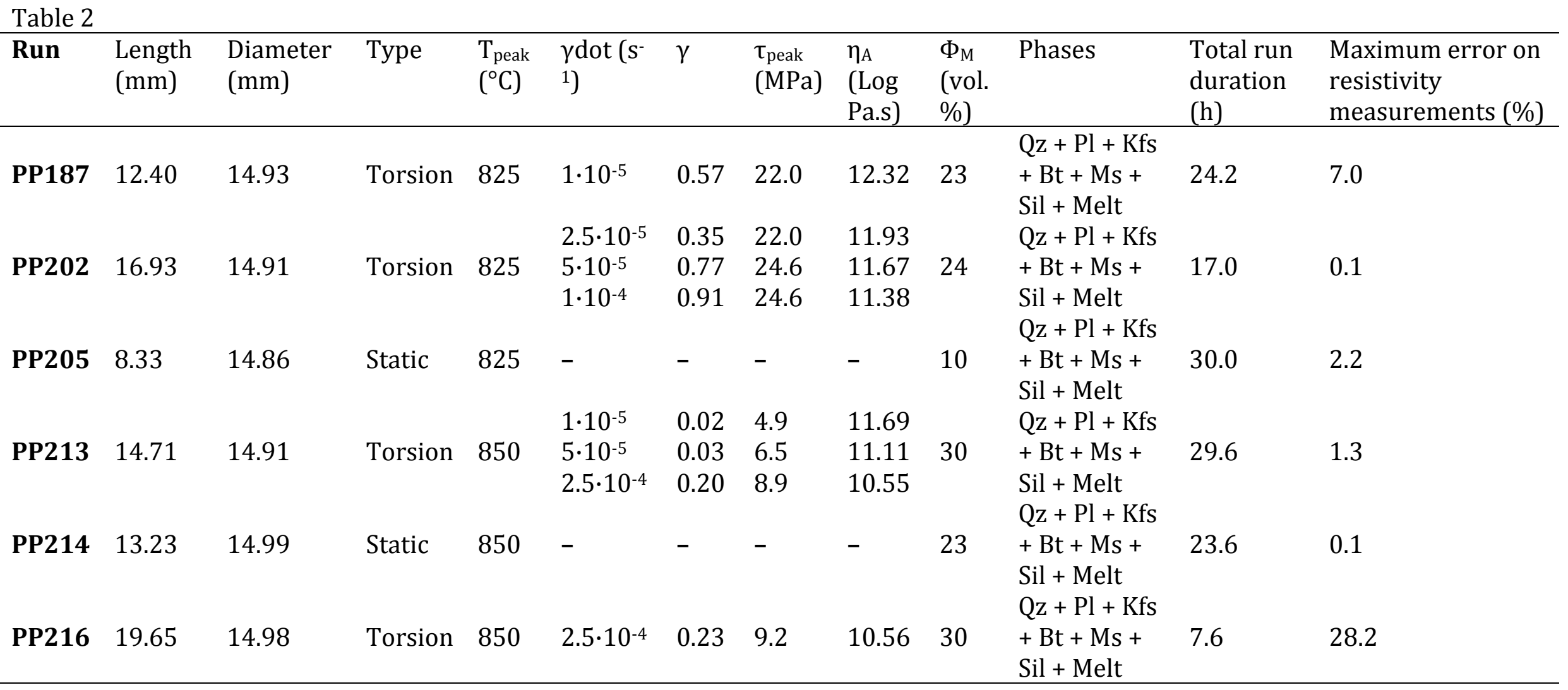


Table 3

\begin{tabular}{ll}
\hline Electrical mixing law & Melt resistivity $(\Omega . m)$ \\
\hline Archie's law & 1.87 \\
Modified Archie's law & 2.71 \\
Hashin-Shtrikman upper bound & 2.13 \\
Cubes model & 1.91 \\
Tubes model & 0.97 \\
\hline
\end{tabular}

